Aktif Epilepsili Hastaların Klinik ve Demografik Profili: Türkiye'deki Bir Üçüncü Basamak Hastanesinin Deneyimleri

\title{
Clinical and Demographic Profile of Patients with Active Epilepsy: Experience From a Tertiary Care Hospital in Turkey
}

\author{
Sehnaz Basaran', Muhammed Nur Öğün²
}

1Derince Eğitim ve Araştırma Hastanesi, Nöroloji Kliniği, Kocaeli, Türkiye 2Bolu Abant Izzet Baysal Üniversitesi, Nöroloji Ana Bilim Dalı, Bolu, Türkiye

\section{$\ddot{O} Z$}

GIRIŞ ve AMAÇ: Üçüncü basamak bir hastanede epilepsi polikliniğine başvuran hastaların klinik ve demografik bulgularını araştırmak.

YÖNTEM ve GEREÇLER: Ocak 2016 - Şubat 2018 tarihleri arasında epilepsi polikliniğine başvuran aktif epilepsili 187 hasta retrospektif olarak incelendi. Demografik özelliklerin yanı sıra; nöbet sıklığı, hastalı süresi, nöbet tipi, antiepileptikler, elektroensefalografik (EEG) ve manyetik rezonans görüntüleme (MRG) bulguları kaydedildi.

BULGULAR: Hastaların yaş ortalaması 36,9 $\pm 13,1$; ve \% 54,5'i erkekti. Ailede epilepsi öyküsü 48 hastada (\% 25.7) bulundu. 35 hastada (\% 18.7) ebeveynler arasinda akraballk vardı. En sık görülen risk faktörleri kafa travması, febril konvülsiyon ve perinatal problemler idi. Fokal nöbetler \% 67.9, jeneralize nöbetler\% 29.3, sinıflandırllamayan nöbetler\% 2.7 idi. 107 hastanin (\% 57.2) beyin MR'ı ve 57 hastanin (\% $30.5)$ interiktal EEG'si normaldi. Hastalarin toplam 116'sl (\% 62) monoterapi alırken, $71^{\prime} i(\% 38)$ polyterapiye almaktaydl.

TARTIŞMA ve SONUÇ: Bu çalışmada, hastaların klinik ve demografik verileri literatür ile uyumlu idi. Kapsamlı epilepsi kliniklerinde düzenli takip ile yapılan ayrıntılı muayenenin nöbetlerin önlenmesinde ve daha iyi sonuç alınmasında potansiyel bir fayda sağlayacă̆ına inanıyoruz.

Anahtar Kelimeler: epilepsi, demografik, klinik

\begin{abstract}
INTRODUCTION: To investigate the clinical and demographic findings of patients at epilepsy outpatient clinic of a tertiary care hospital.
\end{abstract}

METHODS: We retrospectively analysed one hundred and eighty-seven patients with active epilepsy who admitted to our epilepsy clinic between January 2016 and February 2018. In addition to demographic characteristics, we evaluated clinical variables such as; seizure frequency, duration of illness, type of seizures, antiepileptics, electroencephalographic (EEG) and magnetic resonance imaging (MRI) findings.

RESULTS: The mean age of the patients were 36,9 $\pm 13,1$ years; and $54.5 \%$ were male. Family history of epilepsy was found in 48 patients (25.7\%), and 35 patients (18.7\%) had a kinship between parents. The most frequent risk factors were head trauma, febrile convulsions and perinatal problems. Partial seizures was seen in $67.9 \%$, generalised seizures in $29.3 \%$ and unclassified seizures in 2.7\%. Brain MRI of 107 patients (57.2\%) and interictal EEG of 57 patients (30.5\%) was normal. A total of $116(62 \%)$ received monotherapy, while $71(38 \%)$ continued on polytherapy.

DISCUSSION and CONCLUSION: In this study, clinical and demographic data of the patients were consistent with the literature. We believe that detailed examination with regular follow-up in comprehensive epilepsy clinics would provide a potential benefit in preventing seizures and better outcome.

Keywords: epilepsy, demographics, clinic

İletişim / Correspondence:

Dr. Muhammed Nur Ögün

Bolu Abant Izzet Baysal Üniversitesi, Nöroloji Ana Bilim Dall, Bolu, Türkiye

E-mail:dr.mogun@gmail.com

Başvuru Tarihi: 24.04.2019

Kabul Tarihi: 07.08.2019 


\section{INTRODUCTION}

Epilepsy is a clinical condition that results in abnormal, repetitive and synchronized neuronal discharges of the brain (1). This disease has a bimodal distribution with a peak in early childhood and late-middle aged adulthood (2). Generally one percent of people suffer from epilepsy in their lifetime. About 50 million people worldwide live with active epilepsy $(2,3)$. Epidemiologic studies revealed that these rates are increased in low and middle income countries (3). Consequently, detailed documentation of clinic and demographic variables would have a beneficial effect on prognosis in developing countries like Turkey.

In this study, we aimed to investigate sociodemographic and clinical characteristics of patients with active epilepsy who are treated and followed up regularly at our epilepsy outpatient clinic.

\section{MATERIALS and METHODS}

This study was conducted in epilepsy outpatient clinic of a tertiary care hospital. The epilepsy diagnosis was based on medical history, clinical radiologic electoronecephalographic and laboratory findings. We analysed 282 files from the epilepsy clinic between January 2016 and February 2018. Forty-one patients with inadequate documents, 34 with psychogenic non-epileptic seizures 12 patients with single attacks and 8 people with inappropriate drug use were excluded. After the exclusion period, we reevaluated retrospectively 187 patients with active epilepsy due to the seizure diary, medical records and treatment protocols.

Active epilepsy was defined according to the criteria of the International League Against Epilepsy (ILAE) that characterize patients with a seizure in the last five years or receiving antiepileptics at the time of the assessment (4) .

Age, gender, hand dominance, employment, marital status, age of seizure onset, family history, seizure frequency, duration of disease, risk factors, seizure patterns, antiepileptic treatment, 16-channel scalp EEG and Brain MRI (with epilepsy protocol) findings were documented.
The study was performed in accordance with the Declaration of Helsinki by local ethics committee.

\section{Statistical Analyses}

Data analysis was performed using the Statistical Package for Social Sciences version 17.00 for Windows (SPSS Inc., Chicago, IL, USA) program. Descriptive statistics and frequency analysis were used. Data are presented as mean $\pm \mathrm{SD}$ for quantitative data, number (n) and percent (\%) for categorical data.

\section{RESULTS}

In our study, 187 patients with active epilepsy including 102 males (54.5\%) and 85 females $(45.5 \%)$ were enrolled. The mean age of the patients was $36,9 \pm 13,1$ (min:17, max:74) years. The majority of the patients $(77.6 \%)$ were in the age group of 20 to 50 years. Age distribution of patients are shown in Figure 1.

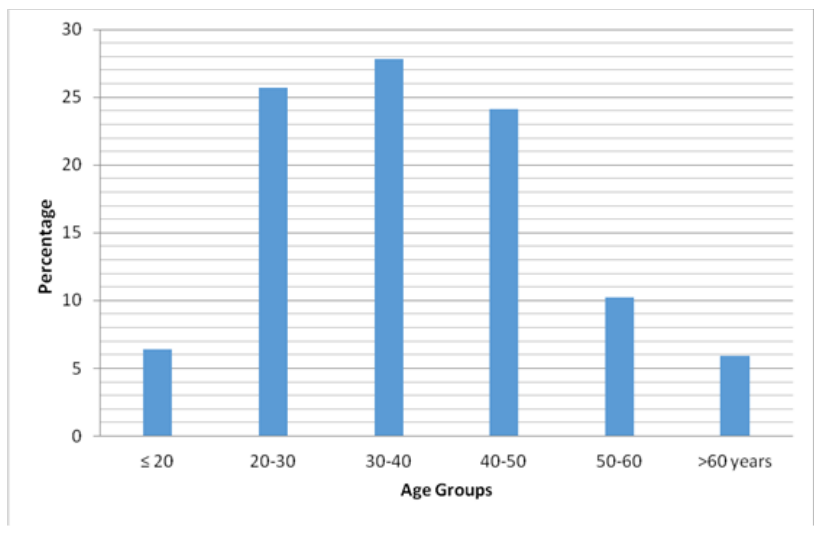

Figure 1. Age distribution of patients with epilepsy

Total of 170 patients $(90.9 \%)$ had a right hand dominance. Family history of epilepsy was positive in 48 patients $(25.7 \%)$ and 35 cases $(18.7 \%)$ had a kinship between parents. Neurological and physical deficits were evident in 22 patients (11.8\%). Mental retardation was found on 12 cases according to the criterias published in the fifth edition of the Diagnostic and Statistical Manual of Mental Disorders (DSM-5)(5) . Sociodemographic characteristics of the patients are shown in Table 1. 
Table 1. Sociodemographic characteristics of patients with epilepsy

$\mathrm{n}$

$\%$

\begin{tabular}{|lll|}
\hline Age (years, mean \pm SD) & $36.9 \pm 13.1$ & \\
\hline Age range & $17-74$ & \\
\hline Age groups & & \\
$\leq \mathbf{2 0}$ years & 12 & 6.4 \\
$\mathbf{2 0 - 3 0}$ & 48 & 25.7 \\
$30-40$ & 52 & 27.8 \\
$40-50$ & 45 & 24.1 \\
$50-60$ & 19 & 10.2 \\
$>60$ years & 11 & 5.9 \\
\hline Gender & & \\
Male & 102 & 54.5 \\
Female & 85 & 44.5 \\
Education (years, mean \pm & $8.6 \pm 3.7$ & \\
SD) & 62 & 33.2 \\
$0-5$ years & 102 & 54.6 \\
5-11 years & 23 & 12.2 \\
$>11$ years & & \\
\hline
\end{tabular}

\begin{tabular}{|lll}
\hline Hand dominance (right) & 170 & 90.9 \\
\hline Socioeconomic Status & & \\
Low & 22 & 11.7 \\
Middle & 145 & 77.5 \\
High & 20 & 10.7 \\
\hline Occupation & & \\
Unemployed & 100 & 53.5 \\
Employed & 81 & 43.3 \\
Retired & 3 & 1.6 \\
Student & 1 & 0.5 \\
Unemployed due to the & 2 & 1.1 \\
seizures & & \\
& & \\
\hline
\end{tabular}

\begin{tabular}{|lll|}
\hline Marital Status & & \\
Single & 52 & 27.8 \\
Married & 133 & 133 \\
Widow/Divorced & 2 & 1.1 \\
\hline $\begin{array}{l}\text { Living Status } \\
\text { (living with family, \%) }\end{array}$ & 183 & 97.9 \\
\hline $\begin{array}{l}\text { Place of Living } \\
\text { Village }\end{array}$ & 8 & \\
Township & 119 & 4.3 \\
City Center & 60 & 63.6 \\
\hline Smoking & 60 & 32.1 \\
\hline Alcohol & 16 & 32.1 \\
\hline Family & 48 & 8.6 \\
\hline Epilepsy & & 25.7 \\
\hline Kinship between parents & 35 & \\
\hline Neurological deficit & 22 & 18.7 \\
\hline Mental retardation & 12 & 11.8 \\
\hline
\end{tabular}

The most common etiology of the seizures was idiopathic (39\%). Head injuries (25.7\%), febrile convulsions $(21.4 \%)$ and neonatal complications $(7.5 \%)$ were other common causes among patients. (Table 2)

\begin{tabular}{|lll|}
\hline \multicolumn{3}{|c|}{ Table 2. Etiologic Factors of patients with Epilepsy } \\
\hline & $\mathbf{N}$ & $\mathbf{\%}$ \\
\hline Febrile Convulsions & 40 & 21.4 \\
\hline Head Injury & 48 & 25.7 \\
\hline $\begin{array}{l}\text { Neonatal } \\
\text { Complications }\end{array}$ & 14 & 7.5 \\
\hline $\begin{array}{l}\text { Cerebrovascular } \\
\text { Disease }\end{array}$ & 4 & 2.1 \\
\hline Intracranial Infections & 3 & 1.6 \\
\hline Brain Lesions & 5 & 2.7 \\
\hline Idiopathic & 73 & 39 \\
\hline
\end{tabular}

The mean age of seizure onset was $19.6 \pm 13.7$ and the mean duration of epilepsy $17.2 \pm 11.9$ years. Frequency of seizures were $2.1 \pm 2.7$ during last three months and $5.8 \pm 7.8$ per year. The most frequent type of seizures was complex partial seizures $(66.3 \%)$, followed by myoclonic seizures (14.4\%), generalised tonic- clonic seizures (13.9\%) and simple partial seizures $(\% 1,6)$. According to the ILAE 1989 classification; our study group consisted of 49 patients $(\% 26,2)$ with extratemporal, 41 patients $(21.9 \%)$ with temporal and 27 patients (14.4 $\%)$ with juvenile myoclonic epilepsy. All the AEDs were taken for single or combination therapies by the patients. Sixty two percent were treated with single AED, while total of $38 \%$ were on polytherapy. (Table 3) 
Table 3. Clinic characteristics of patients with Epilepsy

\begin{tabular}{|c|c|}
\hline & $\%$ \\
\hline $\begin{array}{l}\text { Age of seizure onset } \\
\text { (years, mean } \pm \text { SD) }\end{array}$ & $\begin{array}{l}19.6 \\
( \pm 13.7)\end{array}$ \\
\hline $\begin{array}{l}\text { Duration of illness } \\
\text { (years, mean } \pm \mathrm{SD} \text { ) }\end{array}$ & $\begin{array}{l}17.2 \\
( \pm 11.9)\end{array}$ \\
\hline
\end{tabular}

\section{Seizure frequency}

Last one year (mean $\pm 5.8( \pm 7.8)$

$\mathrm{SD})$ $2.1( \pm 2.7)$

Last three months (mean

$\pm \mathrm{SD}$ )

$\begin{array}{lll}\begin{array}{l}\text { Seizure Types* } \\ \text { Partial }\end{array} & & \\ \text { Simple } & 3 & 1.6 \\ \text { Complex } & 124 & 66.3 \\ \text { Generalised } & & \\ \text { Tonic-clonic } & 26 & 13.9 \\ \text { Absence } & 1 & 0.53 \\ \text { Atonic } & 0 & 0 \\ \text { Myoclonic } & 27 & 14.4 \\ \text { Tonic } & 1 & 0.53 \\ \text { Unknown } & 5 & 2.7\end{array}$

Seizure Classification**

Localisation Related

(Focal) Epilepsies

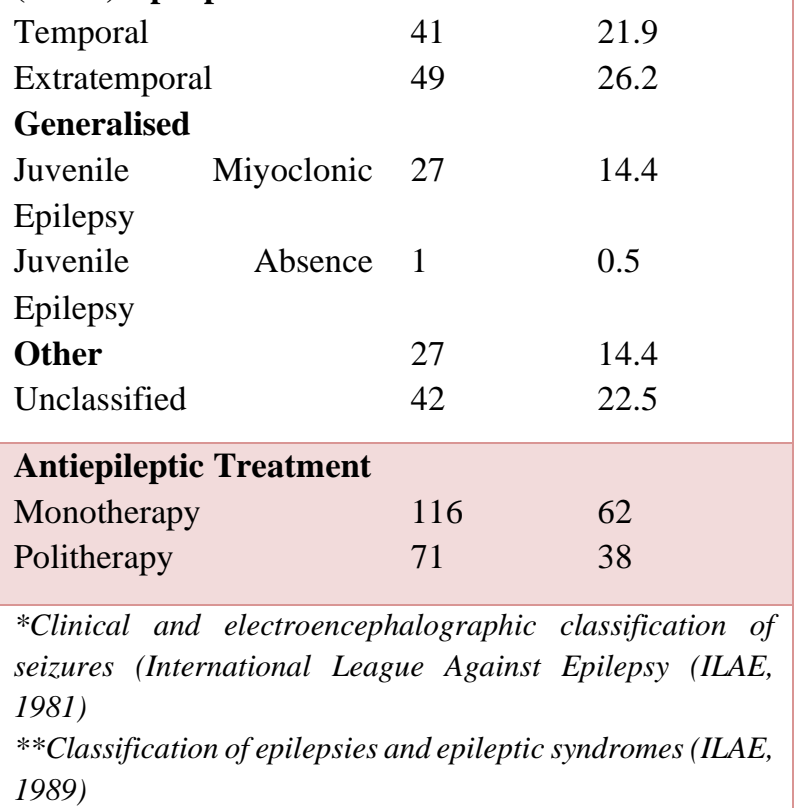

Brain MRI findings were unremerkable in $57.2 \%$ of all cases. Most common cerebral abnormalities were encephalomalasia (13.4\%), ischemic gliosis $(11.2 \%)$ and structural malformations (4.3\%). Interictal EEG recordings showed epileptiform discharges in $58.3 \%$, was normal in $30.5 \%$ and non- specific discharges was noted in $8 \%$ of patients. (Table 4).

\section{Table 4. Electroencephalographic and Magnetic \\ Resonance Imaging Findings of Patients with Epilepsy}

\begin{tabular}{|c|c|c|}
\hline & $\mathbf{n}$ & $\%$ \\
\hline \multicolumn{3}{|l|}{ EEG Findings } \\
\hline Normal & 57 & 30.5 \\
\hline \multicolumn{3}{|l|}{ Epileptiform Discharges } \\
\hline Lateralized & 67 & 35.8 \\
\hline Generalised & 42 & 22.5 \\
\hline Nonspesific Paroxysms & 15 & 8 \\
\hline Unknown & 6 & 3.2 \\
\hline \multicolumn{3}{|l|}{ MRI Findings } \\
\hline Normal & 107 & 57.2 \\
\hline Mesial Temporal Sclerosis & 7 & 3.7 \\
\hline Encephalomalasia & 25 & 13.4 \\
\hline Tumour & 2 & 1.1 \\
\hline Cerebral Atrophy & 5 & 2.7 \\
\hline Ischemic Gliosis & 21 & 11.2 \\
\hline Structural Malformation & 8 & 4.3 \\
\hline Shunt & 1 & 0.5 \\
\hline Foreign Body & 1 & 0.5 \\
\hline Cerebral Heterotrophy & 1 & 0.5 \\
\hline Callosal Atrophy & 1 & 0.5 \\
\hline Neuroglial Cyst & 3 & 1.6 \\
\hline Intracerebral Calcification & 1 & 0.5 \\
\hline Unknown & 4 & 2.1 \\
\hline
\end{tabular}

In our study, total of $62 \%$ were receiving monotherapy, while $38 \%$ were on polytherapy. The most frequent AED was Levetiracetam (24.1\%), followed by sodium valproate $(21.9 \%)$, carbamazepine (7\%) and oxcarbazepine (4.8\%). (Table 5) Distribution of antiepileptic agents used by patients with epilepsy are shown in Figure 2.

\begin{tabular}{|lcc|}
\hline $\begin{array}{l}\text { Table 5. Distribution } \\
\text { patients with epilepsy }\end{array}$ & of & Antiepileptics \\
\hline Drug & $\mathbf{n}$ & \% \\
\hline Levetiracetam & 45 & 24.1 \\
\hline Sodium Valproate & 41 & 21.9 \\
\hline Carbamazepine & 13 & 7.0 \\
\hline Oxcarbazepine & 9 & 4.8 \\
\hline Lamotrigine & 5 & 2.7 \\
\hline Topiramate & 1 & 0.5 \\
\hline Phenytoin & 1 & 0.5 \\
\hline Clonazepam & 1 & 0.5 \\
\hline Zonisamide* & 0 & 0 \\
\hline Lacosamide* & 0 & 0 \\
\hline Pirimidone* & 0 & 0 \\
\hline Polytherapy & 71 & 38.0 \\
\hline *Type of antiepileptics that placed in the polytherapy group \\
\hline
\end{tabular}




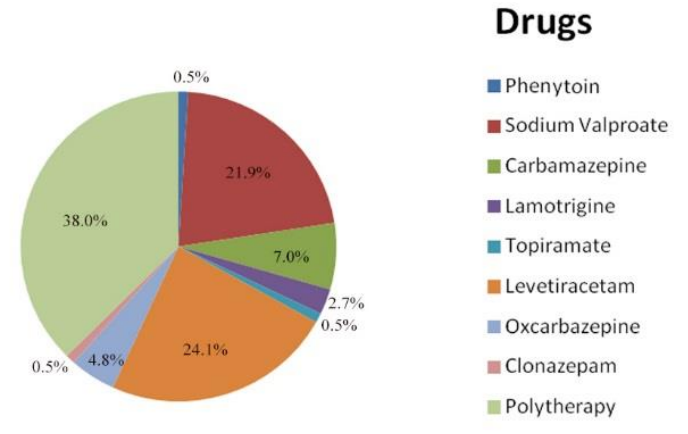

Figure 2. Distribution of antiepileptic drugs used by patients with epilepsy

\section{DISCUSSION}

Epilepsy is a serious and prevalent neurologic disease that ocur in all countries worldwide (2). Assessment of sociodemographic and clinic features of epileptic patients at tertiary care hospital would simplify the treatment strategies and prevention methods for seizures. Accordingly, we aimed to evaluate and update the descriptive data of patients with active epilepsy. In our study, percentage of men $(54.5 \%)$ was slightly more than women $(45.5 \%)$. Studies about gender differences revealed that unprovoked seizures are more frequent in men, while idiopathic generalised epilepsies including juvenile myoclonic epilepsy and absence epilepsy affect more women $(6,7)$. Bharucha et al. reported that men's broad participation in social life may increase their exposure to trauma and provide the development of epilepsy (8). Additionally, some authors suggest that men predominance would depend on socicultural reasons such as; women hide their illness in order to avoid themselves from unmarriagable beliefs or stigmatisation $(3,9)$. In contrast, some studies found no statistically significant gender differences among epileptic patients $(10,11)$.

Consanguineous marriage is a traditional issue, especially in eastern part of Turkey(12). Numerous studies has suggested that consanguinity is a frequent risk factor for seizure disorders in developing countries $(13,14)$. Our study was conducted in a hospital which is located in a north-west township established with massive rural-to-urban migration from eastern regions. We found that $18.7 \%$ of epileptic patients had a kinship between parents. This result may depend on the property of our study group's place of living. On the contrary, some studies reported no association between epilepsy and parental consanguinity at eastern regions. However, these studies reflected a limited population which was comprised of children or young-adult individiuals with normal intelligence $(15,16)$.

Previous reports about risk factors of epilepsy had remerkable methodological limitations $(17,18)$. Consequently, these results were controversial due to different age groups, countries and seizure types (2, 13, 19). Moreover, researchers have focused on risk factors seperately according to various types of epilepsy and epilepsy syndromes (19). Thus, comparing the frequency of certain risk factors between different studies was more difficult. In our study, the most common etiologic factors were family history of epilepsy and head trauma with the same percentage $(25.7 \%)$. Studies demonstrated that $15-37 \%$ of epileptic patients have a positive family history $(19,20)$. Individuals who have epilepsy in their first-degree relatives have a risk about 3-6 times that in the general population (19).

Head trauma increases the risk for seizure development (21). In the United States, cumulative incidence of epilepsy after head trauma ranges between $2 \%$ and $50 \%$, depending on injury severity (22). In a large population-based study in Rochester, Minnesota, $30 \%$ of individuals with head trauma between 15-34 years developed epilepsy, while $8 \%$ of adults older than 65 years (23). Our results were in good agreement with previous reports (21-23).

Strong association between febrile seizures and epilepsy has been well-established from both developed and developing countries for years. On the other hand, the mechanisms underlying this association remains unclear (18). In our study, the second common risk factor was history of febrile convulsions $(21.4 \%)$ which is the most prevalent in studies from Sri Lanka and $\operatorname{Iran}(24,25)$. Additionally, two reports at tertiary clinics from Turkey revealed that febrile convulsions are the second risk factor in epileptic patients $(26,27)$. Percentage of neonatal complications $(7.5 \%)$ took third place in our study. These results were similar with previous investigations (26-28).

Epileptic seizures after cerebrovascular diseases may ocur in early or late stages. It has been estimated 
that long-term cumulative risk of poststroke epilepsy (PSE) vary from $2 \%$ to $15 \%$ (29). In our study 2.1 $\%$ of patients had stroke before seizures.

In developing countries generalized epilepsy is reported to be more frequent, while complex partial seizures are more common in studies conducted in western countries $(28,30)$. Partial seizures are missing according to limited availability to EEG units in poor nations(31). In our study, complex partial seizures $(66.3 \%)$ were the most common type of epilepsy. Thus, our results were similar to that observed in industrial population $(31,32)$. On the other hand, controversial results from developing countries may related to heterogeneity of study population at each region, differences between age groups and variations in methodological settings and diagnostic tests $(8,28)$.

Radiologic abnormalities were detected in $40.7 \%$ of all patients who underwent MRI with standard epilepsy protocol (33). Our findings about neuroimaging abnormalities were correlated with previous studies $(24,34,35)$. In additon, two studies conducted in Iran and Japan reported that brain CT/MRI was abnormal in $26.6 \%$ and $27.4 \%$ respectively, which was lower than our findings (25, 36). This difference may related to lower sensitivity of brain CT for detecting epileptogenic lesions.

Approximately $12.5-50 \%$ of epileptic patients present interictal epileptiform discharges (IEDs) on standard EEG recordings. Sleep deprivation facilitates the appearance of these paroxisms (35). In our study, IEDs were detected in $58.3 \%$ of all patients. Similar results have been shown in studies which were conducted in Japan, Jaipur and Sudan $(34,36,37)$.

About $60-70 \%$ of patients with epilepsy respond well to monotherapy with an appropriate AED. Consistent with previous reports, the majority of the patients were receiving monotherapy as compared to polytherapy (62\% versus $38 \%$ ) in our study (38, 39). The most commonly used AED was Levetiracetam $(24.1 \%)$, followed by sodium valproate $(21.9 \%)$ and carbamazepine $(7 \%)$. The frequent usage of Levetiracetam can be explained by high percentage of partial seizures in the sample and/or physicians choice of new generation AEDs for partial epilepsy.

\section{Limitations of The Study}

Our study has some limitations. First, our sample was small with a retrospective design. Secondly, our study was hospital-based which may differ from population-based studies. Third, absence of pediatric age group in the sample provides a limited comparement. Further population based studies in large groups are needed to evaluate descriptive features of patients with epilepsy.

\section{CONCLUSION}

This report gives a valuable information and reflect a profile about the epileptic patients at a tertiary care hospital in Turkey. We believe that the evaluation of sociodemographic and clinic characteristics with comprehensive studies would provide a potential benefit for the development of treatment strategies and better outcomes.

\section{ACKNOWLEDGMENTS}

We would like to thank Seval Pazarli for organizing and documenting the files of the patients in the epilepsy outpatient clinic.

\section{REFERENCES}

1. Engel Jr J. Report of the ILAE classification core group. Epilepsia. 2006;47(9):1558-68.

2. Sirven JI. Epilepsy: a spectrum disorder. Cold Spring Harb Perspect Med. 2015;5(9):a022848.

3. Fiest KM, Sauro KM, Wiebe S, Patten SB, Kwon C-S, Dykeman J, et al. Prevalence and incidence of epilepsy: a systematic review and metaanalysis of international studies. Neurology. 2017;88(3):296-303.

4. Fisher RS, Acevedo C, Arzimanoglou A, Bogacz A, Cross JH, Elger CE, et al. ILAE official report: a practical clinical definition of epilepsy. Epilepsia. 2014;55(4):475-82.

5. Harris JC. New terminology for mental retardation in DSM-5 and ICD-11. Current opinion in psychiatry. 2013;26(3):260-2.

6. Christensen J, Kjeldsen MJ, Andersen H, Friis ML, Sidenius P. Gender differences in epilepsy. Epilepsia. 2005;46(6):956-60.

7. Carlson C, Dugan P, Kirsch HE, Friedman D, Investigators E. Sex differences in seizure types and symptoms. Epilepsy Behav. 2014;41:103-8.

8. Bharucha NE, Bharucha EP, Bharucha AE, Bhise AV, Schoenberg BS. Prevalence of epilepsy in 
the Parsi community of Bombay. Epilepsia. 1988;29(2):111-5.

9. Banerjee PN, Filippi D, Hauser WA. The descriptive epidemiology of epilepsy - a review. Epilepsy Res. 2009;85(1):31-45.

10. Olafsson E, Hauser WA. Prevalence of epilepsy in rural Iceland: a population-based study. Epilepsia. 1999;40(11):1529-34.

11. Forsgren L. Prospective incidence study and clinical characterization of seizures in newly referred adults. Epilepsia. 1990;31(3):292-301.

12. Akbayram S, Sari N, Akgün C, Dogan M, Tuncer $\mathrm{O}$, Caksen $\mathrm{H}$, et al. The frequency of consanguineous marriage in eastern Turkey. Genet Couns. 2009;20(3):207.

13. Khan H, Mohamed A, Al-Sakini Z, Zulfiquar K, Sohail A, Shaikh R. Consanguinity, family history and risk of epilepsy: A case control study. Gulf Medical Journal. 2012;1(1):4.

14. Chentouf A, Talhi R, Dahdouh A, Benbihi L, Benilha S, Oubaiche ML, et al. Consanguinity and epilepsy in Oran, Algeria: a case-control study. Epilepsy Res. 2015;111:10-7.

15. Huseyinoglu N, Ozben S, Arhan E, Palanci Y, Gunes N. Prevalence and risk factors of epilepsy among school children in eastern Turkey. Pediatr Neurol. 2012;47(1):13-8.

16. Hüseyınoglu N, Palanc1 Y, Günes N, Köse Özlece H. Prevalence of Epilepsy in the University Students Representing a Young Adult Population With Normal Intelligence. Epilepsi: Journal of the Turkish Epilepsi Society. 2014;20(2).

17. Peljto AL, Barker-Cummings C, Vasoli VM, Leibson CL, Hauser WA, Buchhalter JR, et al. Familial risk of epilepsy: a population-based study. Brain. 2014;137(3):795-805.

18. Jablensky A, Johnson R, Bunney W, Cruz M, Durkin M, Familusi J, et al. Neurological, Psychiatric and Developmental Disorders: Meeting the Challenge in the Developing World. Washington DC: Institute of Medicine. 2001:293-5.

19. Berkovic SF, Scheffer IE. Genetics of the epilepsies. Epilepsia. 2001;42:16-23.

20. Steinlein OK. Genetic mechanisms that underlie epilepsy. Nature Reviews Neuroscience. 2004;5(5):400.

21. Christensen J, Pedersen MG, Pedersen CB, Sidenius P, Olsen J, Vestergaard M. Long-term risk of epilepsy after traumatic brain injury in children and young adults: a population-based cohort study. The Lancet. 2009;373(9669):1105-10.

22. Frey LC. Epidemiology of posttraumatic epilepsy: a critical review. Epilepsia. 2003;44:11-7.

23. Hauser WA, Annegers JF, Kurland LT. Incidence of epilepsy and unprovoked seizures in Rochester, Minnesota: 1935-1984. Epilepsia. 1993;34(3):453-8.

24. Senanayake N. Classification of epileptic seizures: a hospital-based study of 1,250 patients in a developing country. Epilepsia. 1993;34(5):812-8.

25. Ebrahimi H, Shafa M, Hakimzadeh Asl S. Prevalence of active epilepsy in Kerman, Iran: a house based survey. Acta Neurol Taiwan. 2012;21(3):115-24.

26. Ünal Y, Aslan Öztürk D, Y1lmaz M, Kutlu G. Demographic and Clinical Findings of Epilepsy Patients who Underwent Follow-up at the Newly Established Clinic of the Muğla Sitk1 Koçman University Faculty of Medicine. Journal of the Turkish Chapter of ILAE.22(1):5-11.

27. Özkara Ç, Atakli D, Baybaş S, Arpaci B, Yilmaz N, Ceyhan A, et al. Evaluation of patients with epilepsy: an outpatient clinic based study. Seizure - European Journal of Epilepsy. 1996;5(2):109-13.

28. Espinosa Jovel CA, Pardo CM, Moreno CM, Vergara J, Hedmont D, Sobrino Mejía FE. Demographic and social profile of epilepsy in a vulnerable low-income population in Bogotá, Colombia. Neurología (English Edition). 2016;31(8):528-34.

29. Zelano J. Poststroke epilepsy: update and future directions. Ther Adv Neurol Disord. 2016;9(5):424-35.

30. Onal AE, Tumerdem Y, Ozturk MK, Gurses C, Baykan B, Gokyigit A, et al. Epilepsy prevalence in a rural area in Istanbul. Seizure - European Journal of Epilepsy. 2002;11(6):397-401.

31. Luengo A, Parra J, Colás J, Rámos F, Carreras $\mathrm{T}$, Fernández-Pozos MJ, et al. Prevalence of Epilepsy in Northeast Madrid. J Neurol. 2001;248(9):762-7.

32. Forsgren L. Prevalence of epilepsy in adults in northern Sweden. Epilepsia. 1992;33(3):450-8.

33. Spencer D. MRI (Minimum Recommended Imaging) in Epilepsy. Epilepsy Curr. 2014;14(5):261-3. 
34. Hussein A, Eltahir A, Yasin F, Malkaldar M, Amira Sidig MB, Ahmed E, et al. Clinical Presentation of Epilepsy among Adult Sudanese Epileptic Patients Seen In Sheik Mohamed Kheirs Friday Epileptic Clinic-SUDAN. Brain. 2007;5:4.2.

35. Werhahn KJ, Hartl E, Hamann K, Breimhorst M, Noachtar S. Latency of interictal epileptiform discharges in long-term EEG recordings in epilepsy patients. Seizure. 2015;29:20-5.

36. Matsuura M, Oana Y, Kato M, Kawana A, Kan R, Kubota H, et al. A Multicenter Study on the Prevalence of Psychiatric Disorders among New Referrals for Epilepsy in Japan. Epilepsia. 2003;44(1):107-14.

37. Panagariya A, Surekha RK, Sharma B, Hrishikesh K, Agarwal N. Clinical profile of epilepsy, in a tertiary care centre of North-west India. J Indian Med Assoc. 2011;109(1):14-8.

38. Gupta A, Desai C. Profile of epilepsy in a tertiary care public sector hospital of western India. 2017. 2017;4(7):5.

39. Nevitt SJ, Sudell M, Weston J, Smith CT, Marson AG. Antiepileptic drug monotherapy for epilepsy: a network meta-analysis of individual participant data. Cochrane Database of Systematic Reviews. 2017(6). 